\title{
Host Suitability of Weeds and Forage Species to Root-Knot NEMATODE Meloidogyne graminicola AS A FUNCION OF IRRIGATION MANAGEMENT ${ }^{1}$
}

\author{
Hospedabilidade de Plantas Daninhas e Espécies Forrageiras ao Nematoide das Galhas \\ Meloidogyne graminicola em Função do Manejo da Irrigação
}

NEGRETTI, R.R.D. ${ }^{2}$, MANICA-BERTO, R. ${ }^{3}$, AGOSTINETTO, D. ${ }^{4}$, THÜRMER, L. ${ }^{4}$, and GOMES, C.B. ${ }^{3}$

\begin{abstract}
The irrigated rice production can be limited by various phytopathogenic agents, including root-knot nematodes (Meloidogyne spp.). Thus, the aim of this research was to check the host suitability of plant species most often found off-season and during rice cultivation, to root-knot nematode Meloidogyne graminicola, under two irrigation managements. Two experiments were conducted in a completely randomized design. In the first experiment seven plant species that occur in an area of rice cultivation, in fallow, offseason were evaluated. For the second experiment nine weed species infesting the irrigated rice culture were tested in rainfed and flooding conditions. The sixteen species, kept individually in pots with sterilized substrate, were inoculated with 5,000 eggs and second stage juveniles (J2) of nematode. BRS 410 IRGA rice plants inoculated with M. graminicola were used as control. Two months after inoculation, the root system of each plant was evaluated for number of galls and nematode reproduction factor. It was verified that the species of off-season of rice cultivation Sida rhombifolia, Raphanus raphanistrum, Spergula arvensis, Lotus corniculatus and Trifolium repens, and, during the cycle of rice cultivation, Aeschynomene denticulata, Leersia hexandra, are immune to nematode. The plant species offseason, Avena strigosa and Lolium multiflorum and of cultivation, Alternanthera philoxeroides, red rice, Echinochloa crusgalli, Cyperus difformis, Cyperus esculentus, Cyperus iria and Fimbristylis miliacea would behave as hosts of $M$. graminicola, mostly under rainfed conditions.
\end{abstract}

Keywords: hosts, reproduction, susceptibility, Oryza sativa.

RESUMO - A produção de arroz irrigado pode ser limitada por vários agentes fitopatogênicos, entre eles os nematoides das galhas (Meloidogyne spp.). Dessa forma, objetivou-se neste estudo avaliar a hospedabilidade de espécies de plantas, encontradas com maior frequência no entrecultivo e durante o periodo de cultivo do arroz irrigado, ao nematoide das galhas, Meloidogyne graminicola, sob dois manejos da irrigação. Para isso, foram realizados dois experimentos em delineamento completamente casualizado. No primeiro experimento, foram testadas sete espécies vegetais que ocorrem em área de arroz irrigado, em pousio, no periodo de entrecultivo. Para o segundo experimento, testaram-se, em condições de sequeiro e alagamento, nove espécies de plantas daninhas infestantes da cultura do arroz irrigado. As 16 espécies vegetais, mantidas individualmente em vaso com substrato esterilizado, foram inoculadas com 5.000 ovos e juvenis de segundo estádio $\left(J_{2}\right)$ do nematoide. Plantas de arroz BRS IRGA 410 inoculadas com M. graminicola foram utilizadas como testemunhas. Dois meses após a inoculação, o sistema radical de cada planta foi avaliado quanto ao número de galhas e fator de reprodução do nematoide.

Recebido para publicação em 30.8.2013 e aprovado em 2.6.2014.

2 Instituto Federal de Educação, Ciência e Tecnologia do Rio Grande do Sul - IFRS, Ibirubá-RS, Brasil, <negretti.rafael@gmail.com>; ${ }^{3}$ Empresa Brasileira de Pesquisa Agropecuária, Embrapa Clima Temperado, Pelotas-RS, Brasil; ${ }^{4}$ Universidade Federal de Pelotas - UFPel, Capão do Leão-RS, Brasil.

Planta Daninha, Viçosa-MG, v. 32, n. 3, p. 555-561, 2014 
Verificou-se que as espécies de entrecultivo da cultura do arroz irrigado Sida rhombifolia, Raphanus raphanistrum, Spergula arvensis, Lotus corniculatus $e$ Trifolium repens $e$, durante o ciclo de cultivo do arroz irrigado, Aeschynomene denticulata e Leersia hexandra são imunes ao nematoide. As espécies vegetais de entrecultivo, Avena strigosa e Lolium multiflorum, e as de cultivo, Alternanthera philoxeroides, arroz-vermelho, Echinochloa crusgalli, Cyperus difformis, Cyperus esculentus, Cyperus iria e Fimbristylis miliacea, comportam-se como hospedeiras de $\boldsymbol{M}$. graminicola, principalmente em condições de sequeiro.

Palavras-chave: hospedeiro, reprodução, suscetibilidade, Oryza sativa.

\section{INTRODUCTION}

In Brazil, about 2.8 million hectares are cultivated with rice annually, of which over one million are located in the Brazilian states of Rio Grande do Sul (RS) and just over 150 thousand in Santa Catarina (SC). The country occupies a prominent position in the global paddy setting, with a total production of 11.2 million tonnes, standing out as the largest producer outside Asia (CONAB, 2012; FAO, 2012). However, the level of productivity considered ideal for the culture has not yet been reached due to weed interference and attack by pests and plant pathogens.

Among the pests affecting irrigated rice, plant parasitic nematodes are pathogens that infect both the aerial part and the root system of the parasitized plants, and may considerably reduce the culture yield (Karssen \& Moens, 2006. Meloidogyne graminicola is considered one of the species with the greatest potential for damage to irrigated rice culture, reducing productivity between $11 \%$ and $80 \%$ (Padgham et al., 2004; De Waele \& Elsen, 2007). In Brazil, only in the 1990s was reported the presence of $M$. graminicola in irrigated rice culture (Sperandio \& Monteiro, 1991). Subsequently, the widespread occurrence of $M$. graminicola was related (Est. VS1) in irrigated rice fields of the central geological depression of Rio Grande do Sul (Steffen et al., 2007) and in Santa Catarina State (Gomes et al., 2009).

The Meloidogyne genus is considered the most important mainly due to its wide host range that includes more than 3,000 species of wild and cultivated plants (Hussey \& Janssen, 2002). Among the Meloidogyne spp. Weed host, Amaranthus spinosus, Bidens pilosa,
Portulaca oleracea (Brito et al., 2008), Cyperus rotundus, Amaranthus spp., Chenopodium album and Digitaria sp. are often cited in the literature (Myers et al., 2004).

Due to its wide polyphagia, $M$. graminicola survives and reproduces in off-season on weeds and forage crops growing on fallow plants, contributing to the increase of inoculum in the soil, and then parasitizing rice cultivation in the next season (Pokharel et al., 2007). The barnyard grass (Echinochloa spp.), among other weeds (Siciliano et al., 1990; Sperandio \& Amaral, 1994) is reported as good plant host of M. graminicola. However, little is known about the development and reproduction of this nematode in these species in different irrigation situations. In this context, the aim of this research was to check the host suitability of plant species, most often found off-season and during rice cultivation, to rootknot nematode, Meloidogyne graminicola, under two irrigation managements.

\section{MATERIALS AND METHODS}

The experiments were conducted at greenhouse $\left(25 \pm 5{ }^{\circ} \mathrm{C}\right)$ and laboratory conditions, where 16 species of weeds and forage crops were evaluated for resistance to $M$. graminicola. In both experiments, the design was completely randomized with six replications. BR-IRGA 410 rice plants were used as susceptible control (Steffen, 2007).

In the first experiment seven plant species that occur in an area of rice cultivation, in fallow, off-season were tested: Avena strigosa (black oat), Lolium multiflorum (ryegrass), Sida rhombifolia (arrowleaf sida), Raphanus raphanistrum (turnip), Spergula arvensis (corn 
spurrey), Lotus corniculatus (bird's-foot trefoil) and Trifolium repens (white clover (also known as Dutch clover)).

For performing the second experiment, nine weed species the affects the irrigated rice culture were evaluated in rainfed and flooding conditions: Alternanthera philoxeroides (alligator weed), Aeschynomene denticulata (common names vary regionally), Oryza sativa (red rice or Asian rice - ARV), E. crus-galli (cockspur (or cockspur grass), barnyard millet, Japanese millet, water grass, common barnyard grass, or simply "barnyard grass"), C. difformis (known by several common names, including variable flatsedge and smallflower umbrella-sedge), Cyperus esculentus (chufa sedge, nut grass, yellow nutsedge, tiger nut sedge, or earth almond), Cyperus iria (rice flat sedge and rice flatsedge), $F$. miliacea (grasslike fimbry) and Leersia hexandra (southern cutgrass, clubhead cutgrass, and swamp rice grass).

The seeds of $L$. corniculatus and $T$. repens were acquired in the trade, and the species A. philoxeroides was reproduced from new seedling stems of the aerial part. For the other weeds, seeds were collected and placed in rice crops to germinate in commercial substrate $\left(\right.$ Germina Plant $\left.{ }^{\circledR}\right)$ sterilized for two hours at $120{ }^{\circ} \mathrm{C}$. The seeds of S. rhombifolia and $S$. arvensis were scarified, and the ones of C. difformis, C. esculentus, C. iria, F. miliacea and $L$. hexandra, were subjected to different conditions of light and photoperiod to overcome the dormancy. After the emergence, when the plants had between two and four leaves, the transplant was performed to plastic pots with sterilized substrate, keeping one plant per pot.

As inoculum of nematode was used a pure population of $M$. graminicola (Est VS1) kept in a greenhouse in BR IRGA 410 rice plants, with certification of purity of the species performed by electrophoresis with esterase isoenzyme (Carneiro \& Almeida, 2001). The extraction of nematodes was perfomed by grinding the roots into a blender according to the technique described by Hussey \& Barker (1973) and modified by Boneti \& Ferraz (1981).

Five days after transplanting, each plant was inoculated with 5,000 eggs and second stage juveniles (J2) of M. graminicola (initial population) and the inoculum was deposited into three holes approximately two centimeters deep around the plant. The plants from the experiments in the rainfed condition were irrigated when needed, while for the other water management condition, the pots containing the seedlings were filled with water (flooding condition) 48 hours later the inoculation, with water replacement when it was necessary.

Presence or absence of egg masses externally to the roots of the weeds was found at 60 days after inoculation, and the ones that presented were photographed under a microscope. Later, the root systems of the plants were washed and evaluated for number of galls. Next, each root system was processed according to the method of Hussey \& Barker (1973), modified by Boneti \& Ferraz (1981), for subsequent determination of the number of eggs and $\mathrm{J}_{2}$ (final population) and calculation of the reproduction factor ( $\mathrm{RF}$ ) of the nematode/ plant. The plant species with $0<\mathrm{RF}<1$ were considered resistants; $R F \geq 1$, susceptibles; and those with RF equal to zero, immunes (Oostenbrink, 1966).

Data were analyzed for normality by the Shapiro-Wilk test; for homoscedasticity, by the Hartley test; and for independence of waste by graphical analysis. For the variables number of galls, reproductive factors, in both experiments, the transformation $\sqrt{ }(x+0.5)$ was necessary. Subsequently, the data were subjected to analysis of variance ( $p \leq 0.05$ ). In case of statistical significance, the effects of plant species were compared by Tukey test $(p \leq 0.05)$ and the effects of irrigation management by t-test ( $\mathrm{p} \leq 0.05)$.

\section{RESULTS AND DISCUSSION}

Assessing the response of plants occurring off-season of rice to $M$. graminicola (first experiment), it was found that only the forages A. strigosa and L. multiflorum were susceptible to the nematodes $(\mathrm{RF}>1)$. For these two species, it was observed that $M$. graminicola developed typical galss on parasitized roots, although these have not shown statistical difference compared to control (Table 1). However, A. strigosa is considered a poor host of M. graminicola (Pokharel et al., 2007). 
Table 1 - Number of galls, reproduction factor (RF) and reaction of weeds and forages that occurring in the off-season of irrigated rice and remaining under conditions of fallow in the crop, to Meloidogyne graminicola

\begin{tabular}{|l|c|c|c|}
\hline \multicolumn{1}{|c|}{ Species } & $\begin{array}{c}\text { Number of } \\
\text { galls }\end{array}$ & RF & Reaction ${ }^{2 /}$ \\
\hline Oryza sativa $(\mathrm{T})$ & $98.3 \mathrm{a}^{1 /}$ & $74.7 \mathrm{a}$ & $\mathrm{S}$ \\
\hline Avena strigosa & $111.2 \mathrm{a}$ & $15.4 \mathrm{~b}$ & $\mathrm{~S}$ \\
\hline Lolium multiflorum & $65.5 \mathrm{a}$ & $3.8 \mathrm{c}$ & $\mathrm{S}$ \\
\hline Sida rhombifolia & $0.0 \mathrm{~b}$ & $0.0 \mathrm{~d}$ & $\mathrm{I}$ \\
\hline Raphanus raphanistrum & $0.0 \mathrm{~b}$ & $0.0 \mathrm{~d}$ & $\mathrm{I}$ \\
\hline Spergula arvensis & $0.0 \mathrm{~b}$ & $0.0 \mathrm{~d}$ & $\mathrm{I}$ \\
\hline Lotus corniculatus & $0.0 \mathrm{~b}$ & $0.0 \mathrm{~d}$ & $\mathrm{I}$ \\
\hline Trifolium repens & $0.0 \mathrm{~b}$ & $0.0 \mathrm{~d}$ & $\mathrm{I}$ \\
\hline
\end{tabular}

${ }^{1}$ Means followed by the same letter do not differ by the Tukey test ( $\mathrm{p} \leq 0.05)$. T: control, rice plants cultivar BR-IRGA 410 . 느 S: susceptible $(\mathrm{RF} \geq 1)$ and $\mathrm{I}$ : immune $(\mathrm{RF}=0)$.

In A. strigosa and in rice the presence of egg masses was not observed externally to the root. As for L. multiflorum, some external egg masses were detected (Figure 1 and Table 1). These observations demonstrate that the expression of symptoms and reproduction of the nematode is dependent on the type of host (Roese \& Oliveira, 2004). However, it should be emphasized that in irrigated rice, $M$. graminicola usually lays its eggs in a gelatinous mass inside the root (Prasad et al., 2013), a little studied fact to date.

In the other species, the reproduction factors were equal to zero and the plants were immune to the nematode (Table 1). The immunity of $S$. rhombifolia to $M$. graminicola verified in this study corroborates the results observed by Siciliano et al. (1990), which found that plants of this species inoculated with $M$. graminicola neither exhibit galls in the roots nor allowed the nematode reproduction. $S$. arvensis and $T$. repens behaved in a immune way to $M$. graminicola (Table 1). However, some authors describe them as a host of the nematode (Windham \& Pederson, 1992; Dabur et al., 2004). Thus, differences in adverse reactions to the same weed species can be credited to two hypotheses: intraspecific variability of weeds or physiological variation in populations of the nematode (Mônaco et al., 2008; Pokharel et al., 2010).

The immunity response of the species $S$. rhombifolia, $R$. raphanistrum, S. arvensis, $L$. corniculatus and T. repens, verified in this study (Table 1), represents an important information in the adoption of practices for the nematode management in irrigated rice because they reduce the populations of $M$. graminicola. Therefore, the use of pasture land, from the cultivation of turnips, clover and/or bird's-foot trefoil during autumn/winter, presents itself as a management alternative in areas highly infested with $M$. graminicola.

The species L. multiflorum and A. strigosa provided increase to the nematode population (Table 1 ). These plants, especially ryegrass,
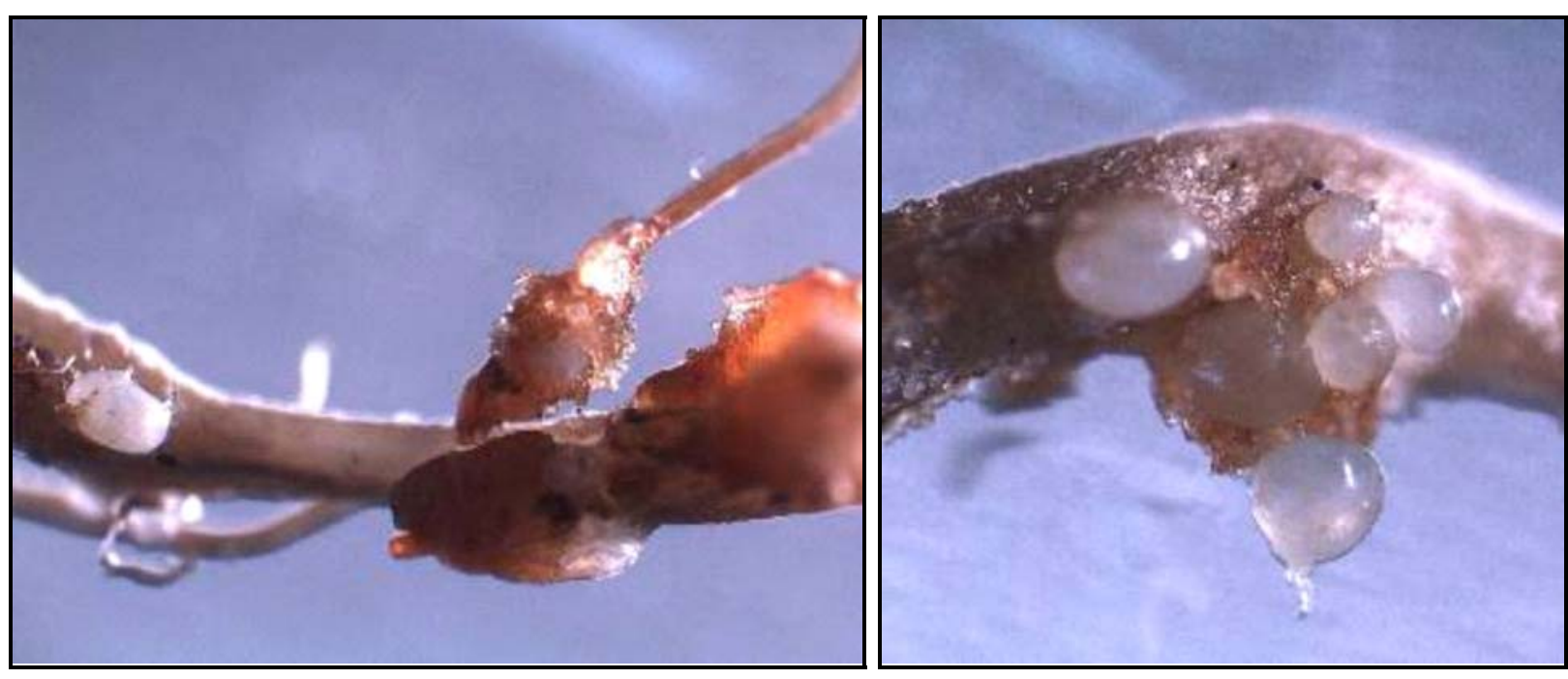

Figure 1 - Egg masses and females of Meloidogyne graminicola observed outside Lolium multiflorum roots. 
are considered the main cultivated or natural annual pastures used in succession to the rice crop. Generally, after the rice harvest, these plants occupy the areas, integrating the process of rotation of cereal with beef cattle or dairy, a widely used system in the lowland areas of the RS, where irrigated rice is grown. Although L. multiflorum and A. strigosa have shown lower susceptibility than the irrigated rice in the field, these host plants can ensure the survival of the nematode and contribute to rapid population increase in the soil, which in turn will constitute the source of primary inoculum for rice cultivation in the next cultivation season.

In the second experiment, there was an interaction between the treatment factors of plant species and managements of irrigation. It was observed in the rainfed system that $M$. graminicola developed a higher number of galls in the BR-IRGA 410 rice cultivar roots (control), followed by A. philoxeroides, O. sativaARV, E. crusgalli, C. difformis, F. miliacea and C. iria, while the species A. denticulata, C. esculentus and $L$. hexandra did not present these symptoms (Table 2). In the flooding condition, it was observed a higher number of galls in the roots of E. crusgalli, C. difformis, O. sativa-ARV, A. philoxeroides, in the control (BR-IRGA 410) and C. iria. The species A. denticulata, C. esculentus, F. miliacea and
L. hexandra did not shown galls in their respective roots in this irrigation system.

In comparing irrigation managements, differences occurred between rainfed and flooding both for variable numbers of galls and nematode reproduction. In the plants of A. philoxeroides, O. sativa-ARV, E. crusgalli and $F$. miliacea, a great number of galls was observed in the rainfed situation (Table 2). Probably in this situation a higher number of $\mathrm{J} 2$ of $M$. graminicola penetrated in the roots of these species, resulting in higher rates of reproduction.

Among the weeds assessed in the rainfed condition, E. crusgalliwas the plant where the nematode had a higher reproduction rate, demonstrating greater susceptibility, followed by the control, C. difformis, O. sativa-ARV, A. philoxeroides, C. iria, C. esculentus and F. miliacea (Table 2). The greater susceptibility of $E$. crusgalli and of the other plants tested in rainfed, $M$. graminicola must be related to favorable conditions for penetration of juveniles of the root system, since in soil subjected to flooding juvenile they had only 48 hours to migrate and be introduced in the root system before the plants are subjected to saturation of the soil with water. The flooding of the soil with irrigation is the main barrier preventing the infection of rice roots by juveniles of $M$. graminicola (Bridge et al., 2005).

Table 2 - Number of galls, reproduction factor (RF) and reaction of species of weeds, that occur in the period of rice cultivation, Meloidogyne graminicola, in irrigation management, rainfed and flooding

\begin{tabular}{|c|c|c|c|c|c|c|}
\hline \multirow{3}{*}{ Species } & \multicolumn{6}{|c|}{ Irrigation management } \\
\hline & Rainfed & Flooding & Rainfed & Flooding & Rainfed & Flooding \\
\hline & \multicolumn{2}{|c|}{ Number of galls } & \multicolumn{2}{|c|}{ RF } & \multicolumn{2}{|c|}{ Reaction $^{2 /}$} \\
\hline Oryza sativa $(\mathrm{T})$ & $138.5 \mathrm{a}^{1 / *}$ & $28.8 \mathrm{a}$ & $88.4 \mathrm{~b} *$ & $7.7 \mathrm{a}$ & $\mathrm{S}$ & $\mathrm{S}$ \\
\hline Alternanthera philoxeroides & $104.0 \mathrm{ab} *$ & $30.8 \mathrm{a}$ & $22.4 \mathrm{~d} *$ & $3.1 \mathrm{bcd}$ & $\mathrm{S}$ & $\mathrm{S}$ \\
\hline Aeschynomene denticulata & $0.0 \mathrm{e}^{\mathrm{ns}}$ & $0.0 \mathrm{c}$ & $0.0 \mathrm{e}^{\mathrm{ns}}$ & $0.0 \mathrm{f}$ & $\mathrm{I}$ & $\mathrm{I}$ \\
\hline Oryza sativa (red rice) & $100.3 \mathrm{ab} *$ & $38.0 \mathrm{a}$ & $38.0 \mathrm{c} *$ & $3.7 \mathrm{bcd}$ & $\mathrm{S}$ & $\mathrm{S}$ \\
\hline Echinochloa crusgalli & $88.7 \mathrm{~b} *$ & $45.0 \mathrm{a}$ & $110.2 \mathrm{a} *$ & $5.4 \mathrm{ab}$ & $\mathrm{S}$ & $\mathrm{S}$ \\
\hline Cyperus difformis & $51.2 \mathrm{c}^{\mathrm{ns}}$ & $38.3 \mathrm{a}$ & $51.8 \mathrm{c}^{*}$ & $3.9 \mathrm{bc}$ & $\mathrm{S}$ & $\mathrm{S}$ \\
\hline Cyperus esculentus & $0.0 \mathrm{e}^{\mathrm{ns}}$ & $0.0 \mathrm{c}$ & $14.0 \mathrm{~d}^{*}$ & $0.1 \mathrm{ef}$ & $\mathrm{S}$ & $\mathrm{R}$ \\
\hline Cyperus iria & $12.3 \mathrm{~d}^{\mathrm{ns}}$ & $11.2 \mathrm{~b}$ & $20.4 \mathrm{~d}^{*}$ & $1.9 \mathrm{~cd}$ & $\mathrm{~S}$ & $\mathrm{~S}$ \\
\hline Fimbristylis miliacea & $24.7 \mathrm{~d}^{*}$ & $0.0 \mathrm{c}$ & $13.8 \mathrm{~d}^{*}$ & $1.5 \mathrm{de}$ & $\mathrm{S}$ & $\mathrm{S}$ \\
\hline Leersia hexandra & $0.0 \mathrm{e}^{\mathrm{ns}}$ & $0.0 \mathrm{c}$ & $0.0 \mathrm{e}^{\mathrm{ns}}$ & $0.0 \mathrm{f}$ & I & I \\
\hline
\end{tabular}

${ }^{1 /}$ Means followed by the same letter in the column analyze species within irrigation management and do not differ by Tukey test (p $\left.\leq 0.05\right)$; ns and * non significant nor meaningful difference, respectively, by t test $(\mathrm{p} \leq 0.05)$, for each species between the managements. T: control, rice plants cultivar BR-IRGA 410. ${ }^{\prime}$ S: susceptible $(\mathrm{RF} \geq 1)$; I: immune $(\mathrm{RF}=0)$ and $\mathrm{R}$ : resistant $(0<\mathrm{RF}<1)$. 
However, after penetration, the nematode can develop normally and have several cycles inside the roots, even at flooding condition.

In the flooding irrigation system, the nematode showed lower $\mathrm{RF}$, comparing to the rainfed system, in the control (irrigated rice), followed by the species E. crusgalli, C. difformis, O. sativa-ARV, A. philoxeroides, C. iria and F. miliacea (Table 2). As for C. esculentus, it has shown to be resistant in the flooding condition and susceptible in the rainfed management; and the species $A$. denticulata and $L$. hexandra were immune to the nematode in both situations. The lowest nematode reproduction at flooding condition is probably due to the reduction hatching and infectivity of the $\mathrm{J} 2$ in the roots of rice plants subjected to this system of irrigation (Bridge et al., 2005). These observations corroborate the occurrence record of $M$. graminicola in rice crops in RS (Sperandio \& Amaral, 1994; Steffen et al., 2007), whose symptom expression has been detected primarily in portions of areas with smallest water surfaces or no water accumulation points.

The off-season species of the irrigated rice crop, S. rhombifolia, $R$. raphanistrum, $S$. arvensis, L. corniculatus e T. repens, and, during the irrigated rice cultivation cycle, $A$. denticulata and $L$. hexandra are immune to $M$. graminicola. The weeds and forage plants that occur off-season, A. strigosa and L. multiflorum, and during the irrigated rice cultivation cycle, A. philoxeroides, O. sativaARV, E. crusgalli, C. difformis, C. esculentus, $C$. iria and F. miliacea, behave as hosts of $M$. graminicola, specially in rainfed situations. Besides, the irrigation water reduces the reproduction of the nematode and the number of galls in A. philoxeroides, O. sativa-ARV, E. crusgalli, C. difformis, C. iria and F. miliacea.

\section{LITERATURE CITED}

BONETI, J. I. S.; FERRAZ, S. MODIFICAÇÃo DO MÉTODO DE HuSSEY AND Barker PaRA A EXTRAÇÃo de OVOS DE MELOIDOGYNE EXIGUA, EM RAÍZES DE CAFEEIRO. Fitopatol. BraS., v. 6, N. 3, P. 553-553, 1981.

BRIDGE, J. et al. Nematodes parasites of rice. In: LUC, M.; SIKORA, R. A.; BRIDGE, J. (Ed.). Plant parasitic nematodes in subtropical and tropical agriculture. 2.ed. Wallingford: CABI Publishing, 2005. 871 p.

Planta Daninha, Viçosa-MG, v. 32, n. 3, p. 555-561, 2014
BRITO, J. A. et al. Identification and characterization of Meloidogyne spp. infecting horticultural and agronomic crops, and weeds in Florida. Nematology, v. 10, n. 5, p. 757-766, 2008.

CARNEIRO, R. M. D. G.; ALMEIDA, M. R. A. Técnica de eletroforese usada no estudo de enzimas dos nematóides das galhas para identificação de espécies. Nematol. Bras., v. 25, n. 1, p. 35-44, 2001.

\section{COMPANHIA NACIONAL DE ABASTECIMENTO-} CONAB. Estatística da produção agrícola. Disponível em: <http://www.ibge.gov.br/home/estatistica/ indicadores/agropecuárialspa/estProdAgr_201203.pdf>. Acesso em: 10 nov. 2012.

DABUR, K. R. et al. Life cycle of Meloidogyne graminicola on paddy and its host range studies. Indian J. Nematol., v. 34, n. 1, p. 80-84, 2004.

DE WAELE, D.; ELSEN, A. Challenges in tropical plant nematology. Ann. Rev. Phytopathol., v. 45, n. 1, p. 457-485, 2007.

FOODANDAGRICULTURE ORGANIZATION OF THE UNITED NATIONS - FAO. Production of cereals and share in world. Disponível em: http://faostat.fao.org/ site/339/default.aspx. Acesso em: 24 de jun. 2012.

GOMES, C. B. et al. Levantamento do nematóide das galhas (Meloidogyne spp.) em arroz irrigado na região Sul do Brasil. Pelotas: Embrapa Clima Temperado, 2009. 15 p. (Boletim de Pesquisa e Desenvolvimento, 87).

HUSSEY, R. S.; BARKER, K. B. A comparison of methods of collecting inocula for Meloidogyne spp., including a new technique. Plant Dis., v. 57, n. 7, p. 1025-1028, 1973.

HUSSEY, R. S.; JANSSEN, G. J. W. Root-knot nematodes: Meloidogyne species. In: STARR, J. L.; COOK, R.; BRIDGE, J. (Ed.). Plant resistance to parasitic nematodes. Wallingford: $C A B$ International, 2002. p. $43-70$.

KARSSEN, G.; MOENS, M. Root-knot nematodes. In: PERRY, R. N.; MOENS, M. (Ed). Plant nematology. Wallingford: CABI Publishing, 2006. p. 59-90.

MÔNACO, A. P. A. et al. Reação de espécies de plantas daninhas a Meloidogyne paranaensis. Nematol. Bras., v. 32, n. 4, p. 279-284, 2008. 
MYERS, L. K. et al. Investigations of weeds as reservoirs of plant-parasitic nematodes in agricultural systems in Northern Florida. In: ANNUAL SOUTHERN CONSERVATIONTILLAGE CONFERENCE FOR SUSTAINABLEAGRICULTURE, 26., 2004, Raleigh. Proceedings... Raleigh: North Carolina State University, 2004. p. 258-267. (Technical Bulletin, 321)

OOSTENBRINK, M. Major characteristics of the relation between nematodes and plants. Nederland: Mededelingen Landbouwhogeschool Wageningen, 1966. 46 p.

PADGHAM, J. L. et al. Yield loss caused by Meloidogyne graminicola on lowland rainfed rice in Bangladesh. J. Nematol., v. 36, n. 1, p. 42-48, 2004.

POKHAREL, R. R. et al. Characterization of isolates of Meloidogyne from rice-wheat production fields in Nepal. J. Nematol., v. 39, n. 3, p. 221-230, 2007.

POKHAREL, R. R. et al. Variability and the recognition of two races in Meloidogyne graminicola. Austr. Plant Pathol., v. 39, n. 4, p. 326-333, 2010.

PRASAD, J. S. et al. Status of rice nematode research in India. 2013. Disponível em: <http://www.rkmp.co.in/ sites/default/files/ris/research-themes/Status>. Acesso em: 5 jan. 2013.
ROESE, A. D.; OLIVEIRA, R. D. L. Capacidade reprodutiva de Meloidogyne paranaensis em espécies de plantas daninhas. Nematol. Bras., v. 28, n. 2, p. 137-141, 2004.

SICILIANO, S. R. et al. Hospedabilidade de plantas a Meloidogyne graminicola no Brasil: Primeira parte. Nematol. Bras., v. 14, n. 1, p. 121-130, 1990.

SPERANDIO, C. A.; AMARAL, A. S. Nematoides fitoparasitas associados ao cultivo de arroz irrigado no Rio Grande do Sul. R. Lav. Arroz, v. 47, n. 417, p. 3-5, 1994.

SPERANDIO, C. A.; MONTEIRO, A. R. Ocorrência de Meloidogyne graminicola em arroz irrigado no Rio Grande do Sul. Nematol. Bras., v. 15, n. 1, p. 24, 1991.

STEFFEN, R. B. et al. Caracterização bioquímica do nematóide das galhas (Meloidogyne spp.) em lavouras de arroz irrigado na região central do Rio Grande do Sul. Ci. Natura, v. 29, n. 1, p. 37-46, 2007.

WINDHAM, G. L.; PEDERSON, G. A. Comparison of reproduction by Meloidogyne graminicola and M. incognita on Trifolium Species. J. Nematol., v. 24, n. 2, p. 257-261, 1992. 